\title{
Effect of Organisational Commitment in Psychological Contract Breach-Organisational Citizenship Behaviour Bond among Medical Doctors
}

\author{
Koomson Samuel \\ PhD Candidate, MBA, BMS, University of Cape Coast
}

\begin{abstract}
Medical doctors are responsible for leading the care of patients. They are perhaps the most valuable assets of healthcare organisations. Yet, indications signal that medical doctors operating in the Upper East and West Regions of Ghana are bedevilled with severe breaches in their psychological contract, which could probably result in low commitment to their organisation and subsequently, stifle their tendency to be good organisational citizens. The study therefore investigated the interceding effect of organisational commitment in the nexus between psychological contract breach and organisational citizenship behaviour among medical doctors in the Upper East and Upper West Regions of Ghana. 214 medical doctors participated in the study. A validated, semi-structured and self-administered questionnaire was employed. The data collected was subjected to Kaiser-Meyer-Olkin measure of sampling adequacy and Bartlett test of sphericity, as well as reliability and validity tests. Mediating effect was conducted. Control variables were sex, age, employment type and tenure. Significant level was set at 5\%. Partial-least squares structural equation modelling was used to analyse the data, with the help of Smart PLS 3.0M.3 software. Consistent with expectations, organisational commitment partially mediated the association between psychological contract breach and organisational citizenship behaviour among medical doctors working in these two regions. The study therefore settled that organisational commitment lessened the effect of a psychological contract breach on the medical doctors' tendency to be bad organisational citizens. The study therefore recommends managers of Ghana Health Service to consider improving the level of organisational commitment among the medical doctors.
\end{abstract}

Keywords: Organisational commitment, psychological contract breach, organisational citizenship behaviour, medical doctors, healthcare management, health service, Partial-lest square structural equation modelling

\section{Introduction}

The concept of a psychological contract implies that there is an unwritten set of expectations operating at all times between every member of an organisation and the various managers and others in that organisation (Huy \& Takahashi, 2018). As pronounced by Guest, Conway and Briner (1996), psychological contract may offer some indication of the answers to the two fundamental employment relationship questions that individuals pose: 'What can I reasonably expect from my organisation?' and 'What should I reasonably be expected to contribute in return?' Employers may expect employees to do their best on behalf of the organisation: 'to put themselves out for the company'; to be fully committed to its values, to be compliant and loyal; and to enhance the image of the organisation with its customers and suppliers (Rousseau \& Greller, 1994).

Employees, on the other side, may expect to be treated fairly as human beings, to be provided with work that uses their abilities, to be rewarded equitably in accordance with their contribution, to be able to display competence, to have opportunities for further growth, to know what is expected of them, to be given feedback-preferably positive-on how they are doing, to be involved in decision making, and to gain trust in the management of the organisation in keeping their promises (Guest et al., 1996). This assertion is aligned to the $8^{\text {th }}$ and $16^{\text {th }}$ UN Sustainable Development Goals, which seeks to offer decent work and economic 
development for all, and encourage peaceful and inclusive societies for sustainable development respectively (Catholic Agency for Overseas Development, 2015).

Gallup's State of the American Workplace Report (2017) upholds that employees need to be in an environment where there is mutual trust, recognition and respect for one another's efforts and results. Ghana National Healthcare Quality Strategy Report (2017) also highlights the need for management to build a culture of "joy at work" in terms of financing, logistics, recognition and rewards to give room for health professionals to deliver high quality care and be motivated to continuously improve quality. This proclamation is consistent with the modus operandi of Ghana Health Service, which seeks to establish a more equitable, efficient, accessible and responsive health care system in Ghana (Ghana Health Service, 2017).

A psychological contract is said to have been fulfilled if an organisation meets its obligations to an employee, from the employee's vantage, and it serves to build upon the social exchange element (Karagonlar, Eisenberger \& Aselage, 2016), which are founded on trust, reciprocation and reward (Blau, 1964). When a psychological contract is fulfilled, employees become committed to their organisation (Akinbobola \& Zamani, 2018). As a result, employees reciprocate by engaging in organisational citizenship behaviour: beneficial activities that go beyond their formal job duties in order to benefit their employers (Ahmad \& Zafar, 2018). This assertion is described by the Social Exchange Theory, one of the most powerful conceptual paradigms for understanding workplace behaviour (Cropanzano, Anthony, Daniels \& Hall, 2017).

However, evidences suggest possible strong psychological contract breaches among medical doctors working in the Upper East and Upper West Regions of Ghana. These medical doctors, who are relatively few, are being overloaded with work on a daily basis originating from comparatively high hospital admission rates and high doctor-population ratio. Additionally, limited health facilities and hospital beds are available for them to serve patients. This situation is not the same for their co-workers in the other regions of Ghana (Ghana Health Service, 2018). Meanwhile, little recognition is given to them for their efforts, as they are put on the same salary structure with their colleagues in the other regions (Larbi, 2015).

These strong breaches can most likely lead them to be less committed to their organisation. As a result, they are also less likely to be good organisational citizens. This problem is expounded by the social exchange theory, which serves to establish reciprocal obligations from the employee to the employer (Blau, 1964). The theory assumes that if the employee feels the organisation has not done anything for him/her, the employee will be less likely to engage in any positive workplace behaviour (Golden \& Veiga, 2018). In essence, employees' commitment to their organisation can become negative in response to unfavourable treatment in their psychological contract. In the same way, employees may be less willing to offer discretionary and selfless efforts when they are less committed to their organisation (Ko \& Hur, 2014).

Yet, there is paucity of research on the interceding role of organisational commitment in the relationship between psychological contract breach and organisational citizenship behaviour. The few studies that exist in this area have used work engagement or trust as mediating variables. Even more, existing studies have paid less attention to the healthcare sector. Besides, few analysts have employed partial least squaresstructural equations modelling (PLS-SEM), a superior and robust analytical technique in drawing their conclusions. To bridge these gaps in the literature, the current study examined the interceding role of organisational commitment in the relationship between psychological contract breach and organisational citizenship behaviour among medical doctors working in the Upper East and Upper West Regions of Ghana.

\section{Body Text}

The study employed the positivist philosophical paradigm, which believes that there is only one truth. Flowing from this philosophy, the quantitative research approach was employed. Research design was explanatory and the study design was cross-sectional. The target population consisted of all medical doctors working in the Upper East $(n=99)$ and Upper West $(n=152)$ Regions of Ghana, making at total of 251 medical doctors. A sampling frame, comprising all the medical doctors who were available and reachable 
within the time of data collection, was constructed. A census was employed, because, in the view of Israel (2013), it is suitable for smaller populations, such as 200 thereabout. A semi-structured questionnaire was used for data collection hence primary source of data was solicited. The questionnaire was designed to cater for common method variance using the recommendations made by Podsakoff, Mackenzie, Lee and Podsakoff (2003), such as using multiple scale formats.

The questionnaire was made up of 54 items. Section 'A' considered 15 items that measured psychological contract breach among the medical doctors, which were sourced from the study by Conway and Briner (2005), because, it had the highest dimensions covering areas of a) pay, (b) advancement opportunities, (c) employee recognition, (d) fairness in rewards, (e) trust, (f) management support, (g) management involvement and influence, and (h) resource support. Sample item included: Limited materials and equipment are made available to me to perform my job (PCB01). Psychological contract breach was measured on a 7-point Likert-type interval scale ranging from 1: least agreement, 2: less agreement, 3: little agreement, 4: moderate agreement, 5: strong agreement, 6: stronger agreement, to 7=strongest agreement.

Section 'B' covered organisational citizenship behaviour, consisting of 16 items. The Organisational Citizenship Behaviour Scale by Lee and Allen (2002) was employed, because, it has been the most widely used. The 16 items were anchored on a seven-point Likert-type interval scale ranging from 1: never, 2: almost never, 3: occasionally, 4: a moderate, 5: Often times, 6: almost every time, to score 7: every time. Sample item was: 'Willingly give my time to help others who have work-related problems' (OCB-I-2).

Section ' $\mathrm{C}$ ' of the instrument considered organisational commitment among medical doctors. Meyer and Allan's (1997) 19-item scale was employed, since it has been most frequently used by earlier researchers (Akbar, Udin \& Djastuti, 2018; Ayoade, Ogunnaike \& Omotayo, 2018; Clarke \& Mahadi, 2017; Leephaijaroen, 2016; Mensah, 2016; Yildiz, 2018). The 19 items were anchored on a seven-point Likerttype interval scale with score 1=least agreement, 2: less agreement, 3: little agreement, 4: moderate agreement, 5: strong agreement, 6: stronger agreement, and 7=strongest acceptance. Sample item was: 'I really feel as if the hospital's problems are my own' (OCT03). Lastly, 'Section D' of the questionnaire looked at the general information of respondents. The information sought were sex $(1=$ male; $0=$ female), age (in years), employment type ( $1=$ fulltime employment; $0=$ part time $)$, and the number of years worked (in years), as used by earlier researchers (Niesen, Van Hootegem, Vander Elst, Battistelli \& De Witte, 2018; Quratulain, Khan, Crawshaw, Arain \& Hameed, 2018).

The questionnaire was pre-tested at Korle-Bu Teaching Hospital: Ghana's premier healthcare facility located in Accra. Questionnaires were distributed via the Ghana Health Service headquarters in Accra for onward submission to the regional health offices in the Upper East and Upper West Regions to be delivered to medical doctors in their respective health facilities. In addition, the researcher visited the health facilities of the two regions to speed up data collection and avoid a high non-response rate. Of the 251 medical doctors targeted, 218 medical doctors responded to the instrument. Of the 218 questionnaires retrieved, 4 were extremely incomplete (missing values > 5\%), hence they were rejected. The remaining 214 completed questionnaires were used for data processing and analysis. Consequently, a response rate of $85 \%$ was attained. The non-response rate was $15 \%$.

First and foremost, the general information of respondents was analysed using frequencies and percentages. Prior to presenting the descriptive statistics, a test of normality was undertaken using Kolmogorow-Smirnov Test to inform the appropriate measure of central tendency and dispersion to be employed. Subsequently, the data collected were subjected to Kaiser-Meyer-Olkin (KMO) measure of sampling adequacy test and Bartlett Test of Sphericity. Then, reliability and validity tests were run using the guidelines recommended by Hair, Tomas, Ringle and Sarstedt (2014), namely indicator reliability, internal consistency reliability, convergent validity and discriminant validity.

Mediation effect was conducted using the steps proposed by (Preacher \& Hayes, 2004; 2008), since it exhibits higher levels of statistical power compared to (Sobel, 1982) test and the causal steps strategy popularized by (Baron \& Kenny, 1986). Control variables were sex, age, employment type and tenure. 
Significant level was set at 5\%. IBM SPSS Statistics Software for windows, version 24 and Smart PLS 3.0M.3 by Ringle, Wende and Will (2005) were used to analyse the data. The PLS algorithm was run, using the default setting with Initial Weights set at 1.0, Maximum Iterations of 300 and an abort criterion of 1.0E5. The bootstrap of the 214 cases was run, using 5000 bootstrap samples, with no sign changes.

\section{Result and discussion}

General information of respondents: Of the 214 respondents, males were $47.70 \%(n=102)$ and females were $52.30 \%$, implying that the females were slightly more than the males. Allen and Jang (2016) argue that females are better organisation citizens. With respect to the age of respondents, this study adopted the age classifications recommended by Yarlagadda, Murthy and Prasad (2015), namely young adults ( $\leq 30$ years), middle-aged adults (31 to 50 years), and senior adults (>50 years). In line with this age classification, $25.23 \%(\mathrm{n}=54)$ were young adults, $61.68 \%(\mathrm{n}=132)$ were middle-aged adults, and $13.08 \%(\mathrm{n}=28)$ were senior adults. This finding imply that majority of the respondents were middle-aged adults. In other words, majority of the respondents were within the ages of 31 and 50 years, connoting that a vast majority of the respondents were matured hence putting them in a better position to make informed contributions to the present study.

Regarding the employment type of medical doctors, majority were full-time workers $(\mathrm{n}=158,74 \%)$ and the remaining were part-time workers $(n=56,26 \%)$. Niesen et al. (2018) debate that full-time employees spend more time at work, giving them more possibilities to exhibit to be good organisational citizenship behaviour. Finally, the researcher wanted to know the number of years that the respondents have worked with their employer. It came to light that 49 respondents $(23 \%)$ have worked with their employer for less than 5 years, and the remaining 165 respondents $(77 \%)$ have worked with the employer for more than 5 years. Of the 165 respondents who have worked with Ghana Health Service for more than 5 years, 37 respondents have worked for 20 years, 27 respondents have worked for 15 years, and 21 respondents have worked for 10 years. This finding suggest that majority of the respondents have worked with Ghana Health Service for a longer period. Niesen et al. (2018) argued that higher organisational tenure is positively related to better work-related behaviours.

Test of normality: Kolmogorov-Smirnov $\mathrm{Z}$ test indicated that the $p$-values for all the three variables, namely psychological contract breach, organisational citizenship behaviour and organisational commitment were less than the alpha level of 0.05 , hence, the analyst rejected the null hypothesis in favor of the alternate hypothesis and concluded that the datasets for psychological contract breach, organisational citizenship behaviour and organisational commitment were significantly different from a normally distributed data or not normally distributed.

Descriptive statistics: Since the data for all the three variables were not normally distributed, median was used as the measure of central tendency and interquartile range (IQR) was employed as the measure of dispersion. 8 out of the 15 indicators of psychological contract breach showed a median of 5: strong agreement, 5 indicators showed a median of 4: moderate agreement; and the remaining 2 indicators showed a median of 2: less agreement. This finding suggests that majority of the respondents expressed their strong agreement to psychological contract breach, providing evidence of a strong psychological contract breach among the medical doctors working in the Upper East and West Regions of Ghana. The IQR ranged from 2 to 3, connoting that their responses to psychological contract breach were less variegated. Skewness ranged from .067 to .489 and kurtosis ranged from .323 to 1.161, confirming that the data on psychological contract breach was significantly different from a normally distributed data.

Considering organisational citizenship behaviour, all the indicators produced a median of 3: occasionally, denoting that organisational citizenship behaviour was occasionally offered by the medical doctors working in the Upper East and Upper West Regions. The IQR of organisational citizenship behaviour was 1, signally that the responses were not wide-ranging. Skewness ranged from .036 to .468 and kurtosis ranged from .325 to 1.086 , endorsing that the data on organisational citizenship behaviour was not normally distributed.

For organisational commitment, 18 out of the 20 items revealed a median of 3: little agreement, implying that respondents were less committed to their organisation. The IQR of organisational commitment was 1 to 2, indicating that the responses were not varied. Skewness ranged from .103 to .419 and kurtosis ranged 
from .628 to 1.060 , confirming that the data on organisational commitment was significantly different from a normally distributed data.

KMO and Bartlett test of sphericity: Regarding psychological contract breach, the inter-correlations between the indicators were less than 0.05, implying that the indicators correlated with each other. KMO was .93, which was above the minimum of .50. Bartlett's test was highly significant and based on this finding, it is confident to say that factor analysis was appropriate for this data. With respect to organisational citizenship behaviour, the inter-correlations between the indicators were less than 0.05 , implying that the indicators correlated with each other. KMO was .91, which was above the minimum of .50. Bartlett's test was highly significant and based on this finding, it is confident to say that reliability and validity test was appropriate for this data. Considering organisational commitment, the inter-correlations between the indicators were less than 0.05 , implying that the indicators were correlated with each other. KMO was .90 , which was above the minimum of .50. Bartlett's test was highly significant at 5\% and based on this finding, it is confident to say that reliability and validity test was appropriate for this data.

Reliability and validity Tests: Regarding indicator reliability, the indicator loadings for all indicators measuring psychological contract breach and organisational citizenship behaviour met the minimum threshold of .6. However, some of the indicators of organisational commitment were below the minimum threshold, namely OCT05, OCT06 and OCT17. These three items were therefore deleted. The remaining indictors provided assurance of indicator reliability. Composite reliability values for all the three variables were larger than the cut-off of 0.7 , so higher levels of internal consistency reliability has been demonstrated by all three reflective latent variables. With respect to convergent validity, all the average variance extracted (AVE) values passed the acceptable AVE of 0.5 or higher, so convergent validity was confirmed. For discriminant validity, all the indicators loaded higher with their associated constructs than the remaining constructs. Therefore, discriminant validity was deemed to have been well established. In other words, the model has been appropriately specified.

\section{Connection between psychological contract breach and organisational citizenship behaviour:}

Consistent with expectations, the result showed a negative and significant relationship between psychological contract breach and organisational citizenship behaviour among medical doctors working in the Upper East and Upper West Regions of Ghana. The path coefficient was -0.397 (Figure 1) and tstatistics was 8.24 (Figure 2). Simply, the direct path linking psychological contract breach to organisational citizenship behaviour was statistically significant. The study therefore established that psychological contract breach among medical doctors working in the Upper East and West Regions of Ghana led them to be bad organisational citizens.

This conclusion confirmed the study by Francisco (2015) in the Philippines, wherein the author discovered that faculty employees' perceptions of a psychological contract breach negatively affected their organisational citizenship behaviour. The finding also agreed with the revelation by Niesen et al. (2018) that psychological contract was negatively associated with innovative work behaviours among employees from an industrial organisation in the region of Brussel in Belgium.

Interceding role of organisational commitment in the relation between psychological contract breach and organisational citizenship behaviour: The result showed that the two indirect paths linking psychological contract breach to organisational commitment, and organisational commitment to organisational citizenship behaviour were statistically significant at $5 \%$. The t-statistic for the path linking psychological contract breach to organisational commitment was 5.53 and the path connecting organisational commitment to organisational citizenship behaviour recorded a t-statistic of 14.02 (Figure 3). Successively, the variance accounted for (VAF) was computed to be 53\% (Figure 4). This figure fell within the range of $20 \%$ to $80 \%$, hence it was concluded that organisational commitment partially mediated the relationship between psychological contract breach and organisational citizenship behaviour among medical doctors working in the Upper East and Upper West Regions of Ghana. Expressed another way, organisational commitment reduced the effect of a psychological contract breach on the medical doctors' tendency to be show bad organisational citizenship behaviour. 
This deduction mirrored the study by van der Heuvel (2012), where work engagement mediated the relationship between PCB and attitude towards change among employees in nine European countries. Moreover, the discovery resembled the study by Malik and Khalid (2016) in Pakistan, where work engagement partially mediated the relationship between PCB and turnover intentions among employees in private and public sector banks of Lahore.

\section{Conclusion}

The study therefore settled that organisational commitment lessened the effect of a psychological contract breach on the medical doctors' tendency to be bad organisational citizens. The study therefore recommends managers of Ghana Health Service to consider improving the level of organisational commitment among medical doctors working in the Upper East and Upper West Regions of Ghana, such as improving upon their welfare needs, providing study leave, sponsorship for further training, and safe working environment so as to boost organisational citizenship behaviour among them.

\section{References}

[1.] Ahmad, I., \& Zafar, M. A. (2018). Impact of psychological contract fulfilment on organisational citizenship behaviour: Mediating role of perceived organisational support. International Journal of Contemporary Hospitality Management, 30, 1001-1015.

[2.] Akbar, A. B., Udin, S. W., \& Djastuti, I. (2018). Spiritual leadership and employee performance: Mediating role of organisational commitment in Indonesian Public University. Journal of Engineering and Applied Sciences, 13, 4344-4352.

[3.] Akinbobola, O. I., \& Zamani, R. A. (2018). Reciprocity dynamics of psychological contract breach and perceived organisational support on job involvement of private and public organisations. International Journal of Psychology and Behavioural Sciences, 8, 1-6.

[4.] Ayoade E., O., Ogunnaike, O. O., \& Omotayo, A. (2018). An empirical investigation of direct and indirect effect of personality traits on entrepreneurs' commitment of SMEs. Journal of Entrepreneurship Education, 21, 1-11.

[5.] Baron, R. M., \& Kenny, D. A. (1986). The moderator-mediator variable distinction in social psychological research: Conceptual, strategic and statistical considerations. Journal of Personality and Social Psychology, 51, 1173-1182.

[6.] Blau, P. (1964). Exchange and power in social life. New York: Wiley.

[7.] Catholic Agency for Overseas Development (2015). Sustainable development goals: Action for 2030. Retrieved from http://www.statsghana.gov.gh. Accessed on 12/03/2019.

[8.] Clarke, N., \& Mahadi, N. (2017). The significance of mutual recognition respect in mediating the relationships between trait emotional intelligence, affective commitment and job satisfaction. Personality and Individual Differences, 105, 129-134.

[9.] Conway, N. \& Briner, R. B. (2005). Understanding psychological contracts at work: A critical evaluation of theory and research. Oxford: Oxford University Press.

[10.] Cropanzano, R., Anthony, E. L., Daniels, S. R., \& Hall, A. V. (2017). Social exchange theory: A critical review with theoretical remedies. Academy of Management Annals, 11, 479-516.

[11.] Francisco, M. E. (2015). Moderators of psychological contract breach and organisational citizenship behaviours in private educational institutions. Philippine Journal of Psychology, 48(1), 87-114.

[12.] Gallup's State of the American Workplace Report (2017). State of the American workplace. Retrieved from https://www.gallup.com/workplace/238085/state-american-workplace-report2017.aspx. Accessed on 28/01/2019.

[13.] Ghana Health Service (2017). About us. Retrieved from http://www.ghanahealthservice.org/ghscategory.php?cid=2. Accessed on 28/01/2019.

[14.] Ghana Health Service (2018). The health sector in Ghana: Facts and figures. Retrieved from http://ghanahealthservice.org/downloads/Facts+Figures_2018.pdf. Accessed on 25/05/2019.

[15.] Ghana National Healthcare Quality Strategy Report (2017). Key areas to address in leadership and functionality. Retrieved from http://www.moh.gov.gh/wpcontent/uploads/2017/06/National20Quality20Strategy20Ghana.pdf. Accessed on 28/01/2019. 
[16.] Golden, T. D., \& Veiga, J. F. (2018). Self-estrangement's toll on job performance: The pivotal role of social exchange relationships with co-workers. Journal of Management, 44, 1573-1597.

[17.] Guest, D. E., Conway, N., \& Briner, T. (1996). The state of the psychological contract in employment. London: Infrastructure Planning and Design.

[18.] Hair, J. F., Tomas, H., Ringle, C. M., \& Sarstedt, M. (2014). A premier on partial least squares structural modeling. equation Retrieved from https://www.researchgate.net/publication/236032728_A_Primer_on_Partial_Least_Squares_Struct ural_Equation_Modeling. Accessed on 15/03/2019.

[19.] Huy, P. T., \& Takahashi, K. (2018). Determinants of psychological contract breach: An empirical study of Vietnamese employees. Management Research Review, 41, 29-45.

[20.] Israel, G. D. (2013). Determining sample size 1. University of Florida, 1-5.

[21.] Karagonlar, G., Eisenberger, R., \& Aselage, J. (2016). Reciprocation wary employees discount psychological contract fulfilment. Journal of Organisational Behaviour, 37, 23-40.

[22.] Ko, J., \& Hur, S. (2014). The impacts of employee benefits, procedural justice, and managerial trustworthiness on work attitudes: Integrated understanding based on social exchange theory. Public Administration Review, 74, 176-187.

[23.] Larbi, M. D. (2015). The implementation of the single spine salary stricture (SSSS) in Ghana. Unpublished master's thesis, University of Ghana, Legon, Ghana. Retrieved from http://ugspace.ug.edu.gh. Accessed on 12/01/2019.

[24.] Lee, K., \& Allen, N. J. (2002). Organisational citizenship behaviour and workplace deviance: The role of affect and cognitions. Journal of Applied Psychology, 87, 131-142.

[25.] Leephaijaroen, S. (2016). Effect of big-five personality trait and organisational commitments on organisational citizenship behaviour of support staff at Ubon Ratchahani Rajabhat University, Thailand. Kasetsart Journal of Social Sciences, 37, 104-111.

[26.] Malik, S. Z., \& Khalid, N. (2016). Psychological contract breach, work engagement and turnover intention. Pakistan Economic and Social Review, 54, 37-54.

[27.] Mensah, A. O. (2016). Relationship among socio-cultural values, work family conflict and work attitudes: A study of bank managers in Ghana. Unpublished doctoral thesis, Department of Psychology, University of Ghana, Legon, Ghana. Retrieved from http://ugspace.ug.edu.gh/handle/123456789/23381. Accessed on 15/02/2019.

[28.] Meyer, J. P., \& Allan, N. J. (1997). Commitment in the workplace: Theory research and application. Thousand Oaks, USA: Sage Publications.

[29.] Niesen, W., Van Hootegem, A., Vander Elst, T., Battistelli, A., \& De Witte, H. (2018). Job insecurity and innovative work behaviour: A psychological contract perspective. Psychologica Belgica, 57, 174-189.

[30.] Podsakoff, P. M., Mackenzie, S. B., Lee, J.-Y., \& Podsakoff, N. P. (2003). Common method biases in behavioural research: A critical review of the literature and recommended remedies. Journal of Applied Psychology, 88, 879-903.

[31.] Preacher, K. J., \& Hayes, A. F. (2004). SPSS and SAS procedures for estimating indirect effects in simple mediation models. Behaviour Research Methods, Instruments, and Computers, 36, 717-731.

[32.] Preacher, K. J., \& Hayes, A. F. (2008). Asymptotic and resampling strategies for assessing and comparing indirect effects in simple and multiple mediator models. Behaviour Research Methods, 40, 879-891.

[33.] Quratulain, S., Khan, A. K., Crawshaw, J. R., Arain, G. A., \& Hameed, I. (2018). A study of employee affective organisational commitment and retention in Pakistan: The roles of psychological contract breach and norms of reciprocity. The International Journal of Human Resource Management, 29, 2552-2579.

[34.] Ringle, C. M., Wende, S., \& Will, A. (2005). SmartPLS 3.0 (M3) Beta. Retrieved from www.smartpls.de. Accessed at 12/04/2019.

[35.] Rousseau, D. M., \& Greller, M. M. (1994). Human resource practices: Administrative contract makers. Human Resource Management, 33, 385-401.

[36.] Sobel, M. E. (1982). Asymptotic confident intervals for indirect effects in structural equation models. Sociological Methodology, 13, 290-312. 
[37.] van der Heuvel, S. R. H. (2012). The influence of the psychological contract on attitude towards change: What's in it for me? Ridderkerk: Ridderprint.

[38.] Yarlagadda, A., Murthy, J. V. R., \& Prasad, M. H. M. K. (2015). The novel method for human age group classification based on classification based on correlation fractal dimension of facial edges. Journal of King Saud University: Computer and Information Sciences, 27, 468-476.

[39.] Yildiz, E. (2018). A case study on relationships between psychological capital, personality and organisational commitment. International Journal of Business Administration, 9, 99-122. 